\title{
Survival of Brucella abortus in ripened soft cheese made from naturally infected cow's milk
}

\author{
M. PLOMMET *, R. FENSTERBANK *, L. VASSAL **, \\ J. AUCLAIR **, G. MOCQUOT ** \\ avec la collaboration technique de \\ J.C. VACHOT **, M. COURAULT *, D. MUSSET * \\ * INRA, Station de Pathologie de la Reproduction, 37380 Nouzilly, France \\ *: INRA, Laboratoire de Biochimie et Technologie laitières, 78350 Jouy-en-Josas, France
}

\section{Summary}

Milk from eigh heifers experimentally inoculated with a virulent strain of Brucella abortus, and excreting large numbers of these bacteria at calving, was used to make three successive batches of a soft, camembert-type, cheese. Lactic fermentation was induced by a Streptococcus lactis and S. cremoris starter that caused the $\mathrm{pH}$ to fall to 4.5-4.6 after 20 hours. Surface inoculation of the curd with Penicillium caseicolum was performed before ripening at $12{ }^{\circ} \mathrm{C}$. Brucella were enumerated by plating milk or liquid suspensions of cheese on a selective medium. Initially, Brucellae in the milk became concentrated in the curd and counts remained high up to 20 hours, subsequently declining regularly. No Brucella were found after eighteen days. Two groups of 20 mice were each fed 600-670 g of 22-25-day-old cheeses. No Brucella were isolated from these mice autopsied 15 days later. The scientific literature reports long survival times for Brucellae in cheeses of different types prepared from milk to which laboratory-grown cells had been added. It appears that Brucella cells which have multiplied in vivo and been excreted in the milk along with antibodies and inflammatory cells, may be more susceptible to inactivation during the cheesemaking process than laboratory-grown Brucella cells.

Key words: Soft cheese - Brucella - Survival.

\section{Résumé}

Survie de Brucella abortus dans un fromage à pâte molle fabriqué avec du lait de vaches infectées

Le lait de huit vaches infectées expérimentalement par une souche virulente de Brucella abortus, et excrétant massivement cette bactérie au vêlage a servi à la fabrication de trois lots successifs d'un fromage à pâte molle de type camembert. Après emprésurage et acidification par un levain de Streptococcus lactis et S. cremoris donnant après 20 heures un $\mathrm{pH}$ de 4,5-4,6 dans la pâte, le caillé démoulé puis ensemencé par Penicillium caseicolum a été mis à maturer à $12^{\circ} \mathrm{C}$ en ambiance humide. Les Brucella ont été dénombrées dans le lait et dans le fromage par ensemencement sur milieu sélectif. Après une augmentation initiale des Brucella dans le caillé jusqu'à la $20^{c}$ heure, leur nombre a ensuite décru régulièrement jusqu'à disparition après le $18^{\mathrm{e}}$ jour. 
Deux groupes de 20 souris ont reçu du fromage de 22 et 25 jours et en ont consommé au total 600 et 670 grammes respectivement. Aucune Brucella n'a été retrouvée à l'autopsie des souris sacrifiées 15 jours plus tard. La littérature scientifique rapporte des durées de survies supérieures à 20 jours quand différentes souches de Brucella cultivées in vitro sont ajoutées au lait de fabrication. Le fait que les Brucella qui se sont multipliées in vivo soient accompagnées dans le lait de cellules phagocytaires et d'anticorps spécifiques pourrait expliquer cette différence.

Mots clês : Fromage à pâte molle - Brucella - Survie.

\section{Introduction}

Eighteen years after the discovery of the agent of the Malta Fever, Brucella melitensis, goats were shown to be the main reservoir and source of the human disease, the transmission being mostly by consumption of contaminated milk and milk products (ZАммг, 1905). B. abortus, the agent of bovine Brucellosis, not considered at first as pathogenic for human beings, was later isolated from the blood stream of diseased patients. Transmission of the disease to humans was either by direct contact with infected animals or through consumption of milk products (in SPINK, 1956). While there is no doubt about the involvement of raw milk and fresh cheese in causing human infection, the role of mature cheese is still in dispute. Differences in the cheesemaking process, such as acidity of the curd and ripening conditions, may explain the discrepancies, but other experimental conditions should also be considered. If artificially grown Brucella cells are added to milk before cheesemaking, the resistance of these bacteria can be questioned. On the other hand, Brucella in milk from infected commercial herds may be in a more «natural » state of resistance, but it is difficult to design an experiment to demonstrate this, because Brucellae naturally occuring in cows milk are usually found in small numbers which vary from day to day (GiLman et al., 1946). Having previously studied the survival of a mixture of 8 laboratory Brucella strains in experimental soft cheese made from raw milk (Nevot et al., 1962) the availability of milk from experimentally infected cows (FENSTERBANK et al., 1975) prompted us to study the survival of a virulent Brucella abortus strain in Camembert type cheese made as previously. Preliminary results of this study were given in International Dairy Federation Bulletin (Anon., 1980).

\section{Materials and methods}

\section{A. Milk}

Forty five Friesian heifers were inoculated conjunctivally at different stages of pregnancy with about $15 \times 10^{6}$ colony forming units (CFU) of the virulent Brucella abortus reference strain 544 (NCTC 10093). Among the 45 heifers, some aborted, whereas others had a normal or nearly normal pregnancy, with normal milk production. The Brucellae excreted in colostrum and milk were quantitatively determined by 8 samplings from each quarter for 5-7 days, as described elsewhere (PHILIPPON et al., 1971). Eight heifers having a high Brucella count were selected and milked into a special bucket twice a day. On the 22nd of March, the total evening milk from four heifers was 
transferred to an isolated laboratory with cheesemaking facilities. This was repeated again with the milk from four other heifers, on the 4th of April (evening milking) and the 5th of April (morning milking). The evening milk was kept at $12-15^{\circ} \mathrm{C}$ during the night. The three pools of milk were used in three successive cheesemaking experiments.

\section{B. Cheesemaking}

In each experiment twenty liters of pooled raw whole milk were warmed to $32{ }^{\circ} \mathrm{C}$, and inoculated with $1 \%$ of a lactic starter (a mixture of Streptococcus lactis CNRZ 165 and S. cremoris CNRZ 374). After 1 hour incubation, the $\mathrm{pH}$ being then about 6.5 , the milk was transferred into a cheese vat, and commercial liquid rennet $(0.02 \%)$ added ; this induced curdling in 20 minutes. One hour later the curd was cut into large pieces, as is usual in Camembert type cheesemaking, then put into cheese moulds $(85 \mathrm{~mm}$ diameter and $110 \mathrm{~mm}$ high). Drainage of the whey was allowed to proceed until the moulds were removed 20 hours after the rennet had been added. In the meantime, the moulds had been turned twice and the surface inoculated with spores of Penicillium caseicolum. The room temperature was $25^{\circ} \mathrm{C}$ for the first 10 hours, then decreased to $18^{\circ} \mathrm{C}$ thereafter. After removal from the moulds the cheeses were immersed in a $20 \%$ salt solution at $12{ }^{\circ} \mathrm{C}$ for 50 minutes, then were kept in a room at $12{ }^{\circ} \mathrm{C}$, with high humidity for $35-40$ days.

No analyses of the constituents (such as fat or protein determinations) were made but the $\mathrm{pH}$ was measured in milk and curd with a glass electrode and in cheese after preparing a cheese slurry in which a glass electrode was immersed. By any commercial or organoleptic standards, these cheeses could be classified as first class.

\section{Brucella abortus counts}

Milk, and cheese liquified in citrate buffer, were cultured on selective WE medium (RENoux, 1954) by spreading $0.1 \mathrm{ml}$ of each on 10 to 15 petri plates. The plates were incubated for at least 8 days in an atmosphere to which $10 \%$ of $\mathrm{CO}_{2}$ was added. Colonies which developed after 3 days and looked like Brucella were counted and some were taken for identification as described previously (PHILIPPON et al., 1971). The means of the counts and standard errors were calculated and expressed in CFU per $\mathrm{ml}$ or $\mathrm{g}$.

Pieces of curd were taken with a spoon, and pieces of cheese were obtained by cutting a wedge weighing 30-40 g including the soft part and the hard rind of the cheese. These samples were aseptically transferred into a Sorvall Omni-mixer, weighed and four volumes of a $2 \%$ trisodium citrate solution added. After mixing at $5000 \mathrm{rpm}$ for $20 \mathrm{sec}$, the milky suspension obtained was spead onto the plates.

\section{Attempted demonstration of brucellae in cheese by feeding to mice}

In experiments 1 and 3 , cheese, 22 and 25 days post-production respectively, was fed, as the sole feed, on 3 successive days, to 2 groups, each of 20 
female CD-1 mice, (Charles River). A total of $670 \mathrm{~g}$ and $600 \mathrm{~g}$ respectively, were consumed. Fifteen days later the mice were killed; the spleens were aseptically removed, pooled and ground in a glass grinder before being seeded onto $20 \mathrm{WE}$ medium plates and 20 Trypticase Soy Agar (Bio Mérieux, Lyon) plates. Incubation was as described above. Mice are very susceptible animals : intragastric administration of a Brucella melitensis strain has been shown to induce infection in $50 \%$ of mice at a challenge dose of $500 \mathrm{CFU}$, and 1 mouse out of 10 at a dose of $16 \mathrm{CFU}$ (VERGER, 1971). Intragastric or oral infective doses with $B$. abortus 544 were unknown. However, since parenteral infective doses are identical for B. melitensis strain $\mathrm{H} 38$ and B. abortus 544 (ID 80 about $10 \mathrm{CFU}, \mathrm{N}$. Bosseray, personal communication), oral administration should be as efficient to detect a few bacteria for both Brucella strains.

\section{Results}

The three pooled milk samples used in the cheesemaking experiments Nos 1,2 and 3 contained a large number of Brucella cells. After 20 hours of incubation these bacteria were about 5 times more numerous per gram of curd than per $\mathrm{ml}$ of milk (table 1). This may have resulted from bacteria becoming trapped in the clotted milk or from continued multiplication. However after the acidification had taken place, the Brucella counts consistently decreased at such a rate that no Brucella could be recovered after the 18 th day, either by bacteriological culture or by oral administration to experimental mice. None of the 40 mice which received the cheeses ripened for 22 and 25 days were found infected. From what is known of the susceptibility of mice to the oral route of administration, it can be estimated that there were less can 1 CFU of Brucella per $g$ of ingested cheese.

After these negative results were obtained, the remaining cheeses then 40 days old were eaten by the authors and technical staff (some of which having never been in contact with Brucella) without any subsequent health problem being detected by the statutory medical brucellosis surveillance programme.

\section{Discussion}

In our previous study (NEvot et al., 1962), using a very similar soft cheese technology, it was demonstrated that eight strains of Brucella, of the three main species, B. melitensis, B. abortus and B. suis, grown in vitro and added to raw milk, could survive in normally acidified soft cheese ( $\mathrm{pH} 4.5$ at day 1) for more than 29 days, that is far more than the minimal ripening time of 20 days. The present results, with the virulent reference B. abortus strain 544 excreted in the milk of infected cows, are in contrast with the previous results, since Brucellae were not recovered after eighteen days. This difference may be related to the resistance of Brucellae, which may be higher for some strains than for others. However this hypothesis was not tested in the previous experiment where the species of the surviving, Brucellae were not identified. It may also be related to the in vivo adaptation of the challenge bacteria to the milk : they may then be metabolically more active, but also more sensitive to acidity than bacteria grown in vitro. 
TABLE 1

Survival of Brucella abortus during the making and the ripening of soft cheese Survie de Brucella abortus au cours de la fabrication et de la maturation du fromage à pâte molle

\begin{tabular}{|c|c|c|c|c|}
\hline \multirow{3}{*}{$\begin{array}{c}\text { Time } \\
\text { after addition } \\
\text { of starter }\end{array}$} & \multirow{3}{*}{ Sample } & \multicolumn{3}{|c|}{ Brucella counts (CFU/ml or $\mathrm{g})$} \\
\hline & & \multicolumn{3}{|c|}{$\mathrm{N}^{\mathrm{o}}$ of cheesemaking experiment ${ }^{(\mathrm{a})}$} \\
\hline & & 1 & 2 & 3 \\
\hline $1 \mathrm{~h}$ & milk & $\begin{array}{c}1345 \pm 217^{(b)} \\
(6.45)\end{array}$ & $\begin{array}{c}5577 \pm 429 \\
(6.55)\end{array}$ & $\begin{array}{c}8567 \pm 636 \\
(6.55)\end{array}$ \\
\hline $5 \mathrm{~h}$ & fresh curd & $\begin{array}{c}6662 \pm 562 \\
(6.15)\end{array}$ & $\begin{array}{c}37700 \pm 1437 \\
(6.05)\end{array}$ & $\begin{array}{c}16850 \pm 469 \\
(6.05)\end{array}$ \\
\hline $20 \mathrm{~h}$ & $\begin{array}{l}\text { curd out of } \\
\text { mould }\end{array}$ & $\begin{array}{c}6614 \pm 308 \\
(4.6)\end{array}$ & $\begin{array}{c}27830 \pm 1892 \\
(4.6)\end{array}$ & $\begin{array}{c}48962 \pm 2321 \\
(4.5)\end{array}$ \\
\hline $5 \mathrm{~d}$ & fresh cheese & $\begin{array}{c}562 \pm 92 \\
(\mathrm{ND})\end{array}$ & $\begin{array}{c}250 \pm 30 \\
(4.7)\end{array}$ & $\begin{array}{c}5542 \pm 389 \\
(4.8)\end{array}$ \\
\hline $8 \mathrm{~d}$ & & $\begin{array}{l}6 \pm 4 \\
(\mathrm{ND})\end{array}$ & $\begin{array}{c}28 \pm 11 \\
(4.65)\end{array}$ & $\begin{array}{c}252 \pm 36 \\
(4.8)\end{array}$ \\
\hline $12 \mathrm{~d}$ & & $\begin{array}{r}13 \pm 5 \\
\text { (ND) }\end{array}$ & $\begin{array}{l}6 \pm 4 \\
(5.10)\end{array}$ & $\begin{array}{c}83 \pm 17 \\
(4.9)\end{array}$ \\
\hline $15 \mathrm{~d}$ & & $\begin{array}{r}18 \pm 7 \\
(4.85)\end{array}$ & $\begin{array}{l}\text { cont. } \\
(4.9)\end{array}$ & $\begin{array}{c}103 \pm 20 \\
(5.0)\end{array}$ \\
\hline $18 \mathrm{~d}$ & & $\begin{array}{c}13 \pm 5 \\
(4.9)\end{array}$ & $\begin{array}{c}0 \\
\text { (ND) }\end{array}$ & $\begin{array}{c}0 \\
\text { (ND) }\end{array}$ \\
\hline $22 \mathrm{~d}$ & ripened cheese & $\begin{array}{l}(*) \text { cont. }^{(\mathrm{c})} \\
(4.8)\end{array}$ & $\begin{array}{c}0 \\
(6.3)\end{array}$ & $\begin{array}{l}\text { cont. } \\
(6.3)\end{array}$ \\
\hline $25 \mathrm{~d}$ & & $\begin{array}{l}\text { cont. } \\
\text { (5.1) }\end{array}$ & $\begin{array}{c}0 \\
(6.2)\end{array}$ & $\begin{array}{l}\text { (*) cont. } \\
(6.2)\end{array}$ \\
\hline $29 \mathrm{~d}$ & & $\begin{array}{l}\text { cont. } \\
(5.5)\end{array}$ & $\begin{array}{l}\text { cont. } \\
\text { (ND) }\end{array}$ & $\begin{array}{l}\text { cont. } \\
\text { (ND) }\end{array}$ \\
\hline $32 \mathrm{~d}$ & & $\begin{array}{l}\text { cont. } \\
(6.2)\end{array}$ & $\begin{array}{c}0 \\
(\mathrm{ND})\end{array}$ & $\begin{array}{c}0 \\
\text { (ND) }\end{array}$ \\
\hline
\end{tabular}

(a) Each cheesemaking experiment with pooled whole milk from 4 heifers.

(b) Mean $\pm \mathrm{SE}$ of 15 plates per sample and $(\mathrm{pH})$. $\mathrm{ND}=$ not done.

(c) Mould contaminated plates.

(*) Sample fed to mice.

Brucella infection of the udder is associated with 1) the synthesis and excretion of specific antibodies of the IgA and IgM type, evidenced by the milk ring test (Collin, 1976 ; Sutra et al., 1986), and these may interfere with bacterial survival, 2) the mobilisation of somatic cells, as was observed in a similar experiment in which the milk cell count increased, on an average, from $1.12 \times 10^{5} / \mathrm{ml}$ in the control to $6.54 \times 10^{5} / \mathrm{ml}$ in cows excreting large numbers of Brucella. These somatic cells, which included 15 to $30 \%$ mononuclear macrophages (RoguinsKy et al., 1972), may have phagocytized the bacteria present in milk, which were about ten times fewer than the somatic cells, thus promoting an enzymatic lysis. 
The very different results of the many previous studies on the survival of pathogenic bacteria in cheese, varying according to the cheese technology (acidification, length of ripening etc.) (cf. for example the review by Rammell, 1967 and ANON, 1980), have led to the wise conclusion that heat treatment would be the safest way to avoid any hazard. However little is known about the exact mechanisms by which particular bacteria are inactivated in the course of the cheesemaking process. Acidification by lactic bacteria starting without delay and proceeding undisturbed may be one important mechanism among others (NORTHOLT, 1983). In addition, if bacteria grown in vivo are more susceptible to cheesemaking than their counterparts in vitro, as already observed with B. abortus by GILman et al. (1946) and observed by us in the previous and in the present research, then it would be interesting to study more deeply the killing process. In many developing countries, in fact, milk products are often the only source of locally available proteins, but poor sanitary conditions and unhygienic habits result too often in unsafe milk products. If minor improvements in milk technology could, without drastic social changes, help to destroy pathogenic agents, it would be an important step towards a better health for all in developing countries.

Reçu le 18 août 1987. Accepté pour publication le 9 décembre 1987.

\section{References}

ANON, 1980. Behaviour of pathogens in cheese. Fédération Internationale de Laiterie. Int. Dairy Fed. Bull. (122 revised). 5, 11-12.

Collun J.C., 1976. Rôle des différentes immunoglobulines dans l'épreuve de l'anneau utilisée pour le dépistage de la brucellose. Ann. Microbiol. (Inst. Pasteur), 127 b, 177-187.

Fensterbank R., Plommet M., Pardon P., 1975. Traitement de la brucellose bovine par l'oxytétracycline. Ann. Rech. Vét., 6, 43-66.

Gllman H.L., Dahlberg A.C., Marquardt J.C., 1946. The occurrence and survival of Brucella abortus in Cheddar and Limburger cheese. J. Dairy Sci., 29, 71-85,

Nevot A., Mocquot G., Lafont P., Plommet M., 1962. Recherches sur les conditions de survie des bactéries pathogènes dans les fromages à pâte molle. Ann. Insl. Pasteur, 103, 128-134.

Northolt M.D., 1983. Pathogenic micro-organisms in fermented dairy products. Neth. Milk Dairy J., $37,247-248$.

Philippon A., Renoux G, Plommet M., 1971. Brucellose bovine expérimentale. V. Excrétion de Brucella abortus par le colostrum et par le lait. Ann. Rech. Vét., 2, 59-67.

Rammell C.G., 1967. Brucella in dairy products. A review. Aust. J. Dairy Technol., 22, 40-43.

Renoux G., 1954. Sur un milieu sélectif pour l'isolement de Brucella melitensis. Ann. Inst. Pasteur, 87, 325-333,

Roguinsky M., Fensterbank R., Philippon A., 1972. Influence de l'infection brucellique de la mamelle sur la teneur en cellules du lait. Ann. Rech. Vét., 3, 449-457.

Spink W.W., 1956. The nature of Brucellosis. The university of Minnesota Press, Minneapolis.

Sutra L., Caffin J.P., Dubray G., 1986. Role of milk immunoglobulins in Brucella milk ring test. Vet. Microbiol., 12, 359-366.

Verger J.M., 1971. Comparaison des doses infectieuses $50 \%$ (DI 50) de Brucella melitensis inoculée par voie conjonctivale, intragastrique et intrapéritonéale à la souris. Ann. Rech. Vét., 2, $185-196$.

Zамmiт T., 1905. A preliminary note on the examination of the blood of goats suffering from Mediterrenean fever, Reports of the Royal Society of London, Mediterranean fever commission, London, Harrison and Sons, part III, p. 83. 